\title{
Prevalence of behavioral changes in senile dogs
}

\author{
Denis Jeronimo Svicero ${ }^{1}$ Marta Cristina Thomas Heckler ${ }^{1}$ \\ Rogério Martins Amorim ${ }^{\text {* }}$
}

\begin{abstract}
${ }^{1}$ Serviço de Neurologia Veterinária, Departamento de Clínica Veterinária (DCV), Faculdade de Medicina Veterinária e Zootecnia (FMVZ), Universidade Estadual Paulista (UNESP), Prof. Doutor Walter Mauricio Correa s/n, CP 560, 18618-681, Botucatu, SP, Brasil. E-mail: rmamorim@fmvz.unesp.br. "Corresponding author.
\end{abstract}

\begin{abstract}
Owing to improvements in animal welfare, such as in nutrition, preventive medicine, and diagnostic tools, older dogs have become increasingly more prevalent than before. Unfortunately, there is an increasing number of dogs presenting behavioral changes correlated with this growth in the geriatric population. However, many of these owners consider these signs as normal for old age. This study aimed to determine the prevalence of clinical signs related with behavioral changes in the canine geriatric population admitted to the Veterinary Hospital of the Veterinary Medicine and Animal Science College of Universidade Estadual Paulista. The owners of 800 old dogs completed a questionnaire about disorientation, changes in social interaction, loss of training (house soiling), changes in the wake-sleep cycle, physical activity, memory, learning, consciousness, and perception. The results showed that the prevalence of behavioral changes in the canine geriatric population was $90.7 \%$ of dogs that presented at least one of these behavioral changes, and $22.3 \%$ with at least six changes, and with changes in physical activity (58.5\%) and loss of acquired training (30.2\%) being the highest percentage groups that were reported by the owners. We concluded that the prevalence of behavioral changes related with aging in the canine geriatric population was high, and that it was important to include questions about behavioral changes during regular veterinary clinical appointments to identify these clinical signs earlier and investigate the possible causes of the cognitive impairment, including neurological diseases, such as Canine Cognitive Dysfunction Syndrome. Key words: cognitive dysfunction, old dogs, neurology, behavioral changes.
\end{abstract}

Prevalência de alterações comportamentais em cães idosos

RESUMO: Devido à melhora na nutrição e na medicina veterinária, há mais cães idosos do que antes. Infelizmente, acompanhando este crescimento na população geriátrica, houve um aumento no número de cães demonstrando distúrbios de comportamento e senilidade aparente. Entretanto, muitos dos proprietários têm considerado todos esses sinais decorrentes de uma inevitável velhice. O objetivo deste estudo foi obter a prevalência de sinais clínicos relacionados com alterações comportamentais na população canina idosa, atendida no Hospital Veterinário da Faculdade de Medicina Veterinária e Zootecnia da UNESP. Proprietários de 800 cães idosos responderam um questionário sobre desorientação, alterações na interação social, perda de treinamento (urina elou defeca em locais não habituais), alterações no ciclo sono-vigília, atividade física, memória, aprendizagem, consciência e percepção. Os resultados obtidos neste estudo apresentaram uma prevalência de alterações comportamentais na população canina idosa significativa, variando de 22,3\% dos cães, com pelo menos seis alterações comportamentais e, chegando a 90,7\% com pelo menos uma alteração de comportamento, sendo alterações na atividade fisica (58,5\%) e perda de treinamentos adquiridos (30,2\%) os grupos de maior percentual relatado pelos proprietários. Conclui-se que a prevalência de alterações comportamentais relacionadas com o envelhecimento da população canina é alta, sendo importante incluir questões sobre as alterações comportamentais durante as consultas clínicas veterinárias regulares para identificar, o mais precocemente possível, estes sinais clínicos e realizar ações para investigar as possíveis causas de déficit cognitivo, incluindo doenças neurológicas, como a Síndrome de Disfunção Cognitiva canina.

Palavras-chave: disfunção cognitiva, cães idosos, neurologia, alterações comportamentais.

\section{INTRODUCTION}

Owing to improvements in nutrition and veterinary medicine, companion animal lifespan is increasing. Following this is an increasing prevalence of the canine geriatric population, leading to a growth in the number of animals with age-related signs. Dogs have a shorter lifespan compared to humans; and therefore, the aging process is accelerated in these animals (LANDSBERG \& RUEHL,
1997; HEIBLUM et al., 2007; HEAD, 2004). The behavioral changes of old dogs may be considered as part of the normal aging process, or may be attributed towards pathological aging caused by a brain disease that affects learning, motor activity and memory (MILGRAM et al., 1994; LANDSBERG \& RUEHL, 1997; RUEHL \& HART, 1998; ADAMS et al., 2000; CHAN et al., 2002).

Pathological aging with behavioral changes has been described in aged dogs as Canine 
Cognitive Dysfunction Syndrome (CDS), which has clinical, imaging, and histopathological findings similar to human Alzheimer's disease (MILGRAM et al., 1994; CUMMINGS et al., 1996b, c). The main categories describing the clinical signs compatible with CDS is described by DISHA: disorientation; altered Interactions with people or other pets; Sleep-wake cycle alterations, House-soiling and altered Activity level (LANDESBERG et al., 2003). In dogs, senility is accompanied by changes in neurotransmitter activity (CUMMINGS et al., 1996a; HEAD et al., 2001, 2008). Imbalances and decreases in acetylcholine, serotonin, noradrenaline, and dopamine have been reported in animals with CDS. The decrease in dopamine and noradrenaline concentration may contribute to cognitive impairment in older animals (HEIBLUM et al., 2007). In the United States, a study that included 180 dogs with no identifiable health problems revealed that $28 \%$ of the owners of dogs that were 11 to 12 year olds had reported at least one category that was consistent with cognitive dysfunction, and this prevalence increased to $68 \%$ for dogs that were 15 to 16 years old. Ten percent of the owners of the dogs that were 11 to 12 years of age and $36 \%$ of the owners of 15 to 16 year old dogs had reported signs consistent with two or more categories of cognitive dysfunction (NEILSON et al., 2001; LANDSBERG, 2005).

The definitive diagnosis of CDS can only be obtained via a post-mortem neuropathological examination of the brain. However, a CDS presumptive diagnosis can be reached with anamnesis, neurological examinations, cognitive tests (memory evaluation, procedural learning, discrimination of objects and spatial vision), magnetic resonance imaging (MRI) and comparative exclusion of other diseases (LANDSBERG, 2005).

CDS cannot be cured, but palliative options exist that can reduce disease progression (HEIBLUM, 2003). These options include environmental enrichment; pharmacological use of selegiline, nicergoline, propentofiline, and others, as well as the use of a diet rich in antioxidants to protect cell membranes and neutralize free radicals that are neurotoxic (MILGRAM et al., 2002, 2004, 2005; HEIBLUM et al., 2007; HEAD \& ZICKER, 2004). However, behavioral changes in elderly dogs can also be caused by several neurological diseases such as brain tumors, granulomatous meningoencephalitis, infectious meningoencephalitis, vascular diseases, endocrine, metabolic and degenerative disorders (MILGRAM et al., 1994; LANDSBERG \& RUEHL, 1997; ADAMS et al., 2000; CHAN et al., 2002).
Prevalence of behavioral changes in the canine geriatric population can be addressed with improvements in the recognition and treatment of these disturbances, as well as, in the context of translational medicine, with the development of a canine model of aging and dementia in the study of new therapies targeting human cognitive enhancement. In this context the aim of the study was to evaluate the prevalence of behavioral changes in old dogs and relate with clinical signs compatible with CDS.

\section{MATERIALS AND METHODS}

Questionnaires regarding canine behavioral changes were given to the owners of 800 old dogs aged between 7 and 23 years (average age of 10.5 years) from different breeds and both genders (348 males and 452 female). The small dogs $(<9.0 \mathrm{~kg})$ were considered elderly at $11.48 \pm 1.86$ years old; medium dogs $(9.0-23.0 \mathrm{~kg})$ at $10.19 \pm 1.56$ years old; large dogs $(23.1-36.0 \mathrm{~kg})$ at $8.85 \pm 1.38$ years old and giant dogs $(>36.0 \mathrm{~kg})$ at $7.46 \pm 1.27$ years old (GOLDSTON, 1989).

The questionnaire (Figure 1) focused mainly on: disorientation, changes in social interaction, loss of training (house soiling), changes in wake-sleep cycle, physical activity, memory, learning, consciousness and perception (MILGRAM et al., 1994; CUMMINGS et al., 1996a; RUEHL \& HART, 1998).

Question number one was not considered as a clinical sign, but rather, as a method of excluding animals with confounding diseases that would put into doubt the validity of subsequent responses. The size of the animals was standardized according to the Fédération Cynologique Internationale (FCI) and dogs without defined breed were considered of medium size.

Based on the literature and in consideration of dog size variations in our study, we considered the age of 10 years for dogs as being the point in which the prevalence of behavioral changes can increase. In the same manner, we considered the incidence of at least six clinical signs of behavioral changes as being a rigorous, diagnostic criterion for possible CDS (BAIN et al., 2001; NEILSON et al., 2001; LANDSBERG, 2005).

After collecting the responses, descriptive statistics were applied to present the frequency distribution of the variables studied. The chi-square test (PROC FREQ, SAS Institute, 2011) was used to test the association between age, size or sex and the presence of signs compatible with CDS. Logistic regression models (PROC LOGISTIC, SAS Institute, 


\section{Questionnaire}

1- Does your dog have any illness currently?
( ) $\mathrm{N}$
( ) Y Has the disease been treated? ( ) Y ( ) N

2- Has the physical activity of your dog changed?
( ) $\mathrm{N}$
( ) Y ( ) Increased ( ) Decreased

3- Does your dog have any visual impairment? ( ) Y ( ) N

4- Does your dog have any hearing impairment? ( ) $Y \quad($ ) $N$

5- Does your dog present house-soiling? ( ) $\mathrm{Y} \quad$ ( ) $\mathrm{N}$

6- Does your dog hide behind the furniture? ( ) $\mathrm{Y} \quad(\mathrm{l}) \mathrm{N}$

7- Does your dog show any reaction when you arrive home? ( ) Y ( ) N

8- Has your dog been kept away from people and other animals? ( ) Y ( ) N

9- Has your dog been aggressive? ( ) Y ( ) N

10- Has your dog had any difficulty to learn new tasks? ( ) Y ( ) N

11- Does your dog respond when you call it? ( ) $\mathrm{Y} \quad($ ) $N$

12- Does your dog wander through the house and/or get lost? ( ) Y ( ) N

13- Does your dog present difficulty to recognize people who it is familiar with? ( ) Y ( ) N

14- Has your dog's sleep period changed?
( ) $\mathrm{N}$
( ) Y ( ) Increased ( ) Decreased

15- Does your dog present sleeping difficulties?

( ) $\mathrm{N}$
( ) Y How does it demonstrate it?
( ) Scratching
) Coughing
( ) Hyperactivity

( ) Pain ( ) Barking/Howling/Whining ( ) Other:

16- Is your dog afraid of anything that it didn't use to be before?

( ) $\mathrm{N}$

( ) Y What does your dog fear? ( ) Known and/or unknown people ( ) Other animals ( ) Noises (such as fireworks, cars, thunder, rain) ( ) Other:

17- Has your dog been presenting any changes in its behavior?

( ) $\mathrm{N}$

( )Y What changes does your dog present? ( ) Barking to objects ( ) Chewing objects

( ) Digging/Scratching the floor ( ) Licking ( ) Barking/Howling/Whining

( ) Chasing imaginary flies ( ) Other:

Figure 1 - The questionnaire available to owners in printed form. 
2011) were used to estimate the odds of the presence of signs compatible with CDS between age classes $(<10$ and $\geq 10)$, size and sex. Analyses were performed separately for three different scenarios of the clinical signs manifestation ( $\geq 4, \geq 5$ and $\geq 6$ signs). The level of significance was defined as less than 0.05 .

\section{RESULTS}

The prevalence of dogs presenting clinical signs related to behavioral changes is listed, respectively, from at least one behavioral change to at least six: $\geq 1$ $(90.7 \%), \geq 2(76.2 \%), \geq 3(58.8), \geq 4(45.6 \%), \geq 5(32.6 \%)$ and $\geq 6$ clinical signs $(22.3 \%)$.

Among these animals, the following frequencies of clinical signs were evident: $58.5 \%$ showed changes in physical activity, 30.2\% indicating a loss of training, with urination in various locations corresponding to $24.7 \%$ of the sample, and defecation in various locations at $16.7 \%$ of the sample, with $14.8 \%$ showing decreased interaction with people and other animals, $6.3 \%$ showing increased aggressiveness, $33.7 \%$ showing difficulty in learning new tasks, $5.8 \%$ showing disorientation in the house, $53.6 \%$ showing changes in sleep time, and $17.8 \%$ presenting fear behavior.

No differences were reported in the presentation of clinical signs between dogs without a defined breed and dogs with well-defined breed. Prevalence of clinical signs related with at least six signs was $20.6 \%$ and $23.1 \%$, respectively.

The relationship between the different risk factors (age classes $<10$ and $\geq 10$ years, size and sex) demonstrated that age increases the risk of finding behavioral changes in accordance with three definitions that were consistent with CDS, separately, for this study (the presentation of $\geq 4, \geq 5$ and $\geq 6$ signs), according table 1 . Males indicated a higher risk factor of presenting behavioral changes for the three aforementioned definitions consistent with CDS than females. Dog size did not reach statistical significance in all three scenarios $(>4$, $>5,>6$ signs) in which the dogs presented clinical signs; however, this factor demonstrated greater risk with advanced ages.

\section{DISCUSSION}

The high percentage of behavioral changes observed in our study reinforces the importance of the clinician to include anamnesis questions related to these changes. All dogs included in this study were considered healthy by their owners, corresponding to a response of, "no", for question 1 ("Does your dog have any illness currently?") of the questionnaire. These results suggested that the owners had the perception that their dogs were healthy and had normal aging, but with the presentation of a high percentage of behavioral changes. According to others studies, most owners only reported incidences of behavioral changes if they are specifically questioned about it by the clinician (NEILSON et al., 2001; BAIN et al., 2001). Owing to these observations, it is very important that the clinician add questions regarding behavioral changes during anamnesis for older dogs.

The behavioral changes observed in our study, such as alterations in physical activity, sleep-wake cycle disturbances, visual and hearing impairments, difficulties in learning new tasks, antisocial behaviors, fear behaviors and loss of training, may be related to functional deficits arising from injury to the associated regions of the central nervous system. In CDS, there is an excess deposit of $\beta$-amyloid peptide in the vascular endothelium and neurons of the brain, resulting in ischemia and neurodegeneration. Accumulation of $\beta$-amyloid peptides within the brain has been correlated to cognitive impairment in dogs (CUMMINGS et al., 1996a; HEAD et al., 2008). Moreover, imbalances and decreases in neurotransmitters, especially dopamine and noradrenaline, may contribute towards the incidences of cognitive impairment in elderly dogs, and have furthermore been reported in animals with CDS (HEIBLUM et al., 2007). An imbalance of these neurotransmitters within the regions of the amygdala, the raphe nuclei, and the locus coeruleus of the pons, may affect the responses of fear or aggression and alter the sleep-wake cycle, respectively. Furthermore, impairments of learning, because of age, can also be related with changes in hippocampus function and its projections to the cerebral cortex (MILGRAM et al., 1994). However, musculoskeletal, endocrinological, ophthalmological, cochlear and/or others neurological disorders, can also elicit behavioral changes. Among the neurological diseases that cause these changes are brain tumors, granulomatous meningoencephalitis, infectious meningoencephalitis, vascular diseases, metabolic disorders and CDS.

In our study of $800 \mathrm{dogs}, 22.3 \%$ of the owners reported six or more clinical signs related to behavioral changes. Moreover, dogs with 10 years or older showed a 2.5 times greater chance of presenting at least six clinical signs. These findings are similar to those reported by NEILSON et al. (2001) and LANDSBERG (2005). 
Table 1 - Odds ratio (OR) of the presence of clinical signs consistent with Canine Cognitive Dysfunction Syndrome (CDS) between age classes, size and sex.

\begin{tabular}{|c|c|c|c|c|c|}
\hline $\begin{array}{l}\text { Definitions compatible with } \\
\text { the CDS signs }\end{array}$ & Characteristics & $\mathrm{N}$ & presence of clinical signs ( $\%)$ & OR $(95 \% \mathrm{CI})$ & P - Value \\
\hline \multirow{9}{*}{$\geq 4$ signs } & GENDER & & & & \\
\hline & M & 348 & $173(21.6 \%)$ & $1.33(1.00-1.78)$ & 0.048 \\
\hline & $\mathrm{F}$ & 452 & $192(24 \%)$ & - & - \\
\hline & AGE CLASSES & & & & \\
\hline & $\geq 10$ & 348 & $212(26.5 \%)$ & $2.33(1.75-3.11)$ & $<0.001$ \\
\hline & $<10$ & 452 & $152(19.1 \%)$ & - & - \\
\hline & SIZE & & & & \\
\hline & Small x Large & 353 & $164(20.5 \%)$ & $1.40(1.38-2.73)$ & 0.483 \\
\hline & Small x Medium & 756 & $348(43.5 \%)$ & $1.14(1.17-1.55)$ & - \\
\hline \multirow{9}{*}{$\geq 5$ signs } & GENDER & & & & \\
\hline & M & 348 & $131(16.3 \%)$ & $1.51(1.11-2.05)$ & 0.008 \\
\hline & $\mathrm{F}$ & 452 & $130(16.2 \%)$ & - & - \\
\hline & AGE CLASSES & & & & \\
\hline & $\geq 10$ & 373 & $162(20.2 \%)$ & $2.53(1.86-3.44)$ & $<0.001$ \\
\hline & $<10$ & 427 & $99(12.3 \%)$ & - & - \\
\hline & SIZE & & & & \\
\hline & Small x Large & 353 & $123(15.3 \%)$ & $1.49(1.39-3.08)$ & 0.181 \\
\hline & Small x Medium & 756 & $249(31.1 \%)$ & $1.32(1.03-1.81)$ & - \\
\hline \multirow{9}{*}{$\geq 6$ signs } & GENDER & & & & \\
\hline & M & 348 & $88(11 \%)$ & $1.36(1.03-1.92)$ & 0.075 \\
\hline & $\mathrm{F}$ & 452 & $91(11.3 \%)$ & - & - \\
\hline & AGE CLASSES & & & & \\
\hline & $\geq 10$ & 373 & $115(14.3 \%)$ & $2.5(1.78-3.57)$ & $<0.001$ \\
\hline & $<10$ & 427 & $64(8 \%)$ & - & - \\
\hline & SIZE & & & & \\
\hline & Small x Large & 353 & $85(10.6 \%)$ & $2.14(1.16-5.55)$ & 0.106 \\
\hline & Small x Medium & 756 & $173(21.5 \%)$ & $1.34(1.05-1.91)$ & - \\
\hline
\end{tabular}

$* \mathrm{~N}=$ number of dogs; $\mathrm{OR}=$ odds ratio; $\mathrm{CI}=$ confidence interval; $\mathrm{M}=$ male; $\mathrm{F}=$ female.

The male dogs showed a higher risk factor of behavioral changes compared to the female dogs, especially with $\geq 6$ signs ( 1.36 times greater chance). However, there are no available data in the literature comparing sex; therefore, further studies must be carried out to investigate this aspect.

Further studies must be performed to confirm if the behavioral changes in senile dogs, as those obtained in our study, are caused by neurological diseases and if CDS warrants particular emphasis when compared to other brain diseases.

\section{CONCLUSION}

The prevalence of behavioral changes related with aging in the canine geriatric population is high. It is important to include questions about behavioral changes during regular veterinary clinical appointments to identify these clinical signs earlier and carry out actions to investigate the possible causes of cognitive impairment, including neurological diseases as CDS. 


\section{ACKNOWLEDGMENTS}

The authors would like to thank the School of Veterinary Medicine and Animal Science, UNESP, Botucatu, São Paulo, Brazil; the Board of Science and Technology Development (CNPq); PhD José Carlos de Figueiredo Pantoja (who managed statistical analysis) and all dog owners.

\section{BIOETHCS AND BIOSSECURITY COMMITTEE APPROVAL}

This study was approved by the Ethics Committee on Experimentation in the Use of Live Animals of the School of Veterinary Medicine and Animal Science, UNESP, Botucatu, São Paulo, Brazil (reference no. 217/2008).

\section{REFERENCES}

ADAMS, B. et al. The canine as a model of human cognitive agent: recent developments. Prog Neuro-Psychopharm Biol Psychiat, v.24, p.675-692, 2000. Available from: $<$ https://www.ncbi.nlm.nih. gov/pubmed/11191708>. Accessed: Oct. 24, 2016. doi: 10.1016/ S0278-5846(00)00101-9.

BAIN, M.J. et al. Predicting behavioral changes associated with age related cognitive impairment in dogs. J Am Vet Med Assoc, v.218, p.1792-1795, 2001. Available from: <http://avmajournals. avma.org/doi/abs/10.2460/javma.2001.218.1792>. Accessed: Oct. 24, 2016. doi: 10.2460/javma.2001.218.1792.

CHAN, A.D. et al. Visuospatial impairments in aged canines (Canis familiares): the role of cognitive behavioral flexibility. Behav Neurosci, v.116, p.443-454, 2002. Available from: <http://dx.doi. org/10.1037/0735-7044.116.3.443>. Accessed: Oct. 24, 2016.

CUMMINGS, B.J. et al. Beta-amyloid accumulation correlates with cognitive dysfunction in the aged canine. Neurobiol Learn Mem, v.66, p.11-23, 1996a. Available from: <http://dx.doi. org/10.1006/nlme.1996.0039>. Accessed: Oct. 24, 2016.

CUMMINGS, B.J. et al. The canine as an animal model and human aging in dementia. Neurob Aging, v.17, n.2, p.259-268, 1996 b. Available from: <http://dx.doi.org/10.1016/0197-4580(95)020608>. Accessed: Oct. 24, 2016.

CUMMINGS, B.J. et al. Diffuse plaques contain C-terminal A beta 42 and not A beta 40: evidence from cats and dogs. Neurobiol Aging, v.17, p.653-659, 1996c. Available from: <http://dx.doi. org/10.1016/0197-4580(96)00062-0>. Accessed: Oct. 24, 2016.

GOLDSTON, R.T. Geriatrics \& Gerontology. Vet Clin North Am: Small Anim Pract, v.19, p.1-202, 1989.

HEAD, E. et al. Neurobiological models of aging in the dog and other vertebrate species. In: HOFF, P.; MOBBS, C. (Eds.). Functional neurobiology of aging. San Diego: Academic, 2001. p.457-468.

HEAD, E.; ZICKER, S.C. Nutraceuticals, aging, and cognitive dysfunction. Vet Clin North Am: Small Anim Pract, v.34, p.217-228, 2004. Available from: <http://dx.doi.org/10.1016/j. cvsm.2003.09.007>. Accessed: Oct. 24, 2016.
HEAD, E. et al. Oxidative stress, aging, and central nervous system disease in the canine model of human brain aging. Vet Clin North Amer: Small Anim Pract, v.38, p.167-178, 2008. Available from: <http://onlinelibrary.wiley.com/doi/10.1046/ j.1471-4159.2002.00969.x/full>. Accessed: Oct. 24, 2016. doi: 10.1046/j.1471-4159.2002.00969.x.

HEIBLUM, M. et al. "Didy", a clinical case of cognitive dysfunction syndrome. J Vet Behav, v.2, p.68-72, 2007. Available from: <http://dx.doi.org/10.1016/j.jveb.2007.05.002>. Accessed: Oct. 24, 2016.

LANDSBERG, G.; RUEHL, W. Geriatric behavioural problems. In: HOUPT, K. (Ed.). Vet Clin North Amer: Small Anim Pract, p.1537-1559, 1997.

LANDSBERG, G.M. The effects of aging on the behavior of senior pets. In: LANDSBERG, G.M. et al. (Eds.). Handbook of behavior problems of the dog and cat. Edinburgh: Saunders, 2003. p.269-304.

LANDSBERG, G. Therapeutic agents for the treatment of cognitive dysfunction syndrome in senior dogs. Prog in NeuroPsychopharm \& Bio Psy, v.29, p.471-479, 2005. Available from: <http://dx.doi.org/10.1016/j.pnpbp.2004.12.012>. Accessed: Oct. 24, 2016.

MILGRAM, N.W. et al. Cognitive functions and aging in the dog: acquisition of nonspatial visual tasks. Behav Neurosci, v.108, p.57-68, 1994. Available from: <https://www.ncbi.nlm.nih.gov/ pubmed/8192851>. Accessed: Oct. 24, 2016. doi: 10.1037//07357044.108.1.57.

MILGRAM, N.W. et al. Landmark discrimination learning in the dog: Effects of age, an antioxidant fortified food, and cognitive strategy. Neurosci Biobehav Rev, v.26, p.679-695, 2002. Available from: <http://dx.doi.org/10.1016/S0149-7634(02)00039-8>. Accessed: Oct. 24, 2016.

MILGRAM, N.W. et al. Long-term treatment with antioxidants and a program of behavioral enrichment reduces age-dependent impairment in discrimination and reversal learning in beagle dogs. Exp Gerontol, v.39, p.753-765, 2004. Available from: <http:// dx.doi.org/10.1016/j.exger.2004.01.007>. Accessed: Oct. 24, 2016.

MILGRAM, N.W. et al. Learning ability in aged beagle dogs is preserved by behavioral enrichment and dietary fortification: a two-year longitudinal study. Neurobiol Aging, v.26, p.7790, 2005. Available from: <http://dx.doi.org/10.1016/j. neurobiolaging.2004.02.014>. Accessed: Oct. 24, 2016.

NEILSON, J.C. et al. Prevalence of behavioral changes associated with age-related cognitive impairment in dogs. J Am Vet Med Assoc, v.218, p.1787-1791, 2001. Available from: <http:// avmajournals.avma.org/doi/abs/10.2460/javma.2001.218.1787>. Accessed: Oct. 24, 2016. doi: 10.2460/javma.2001.218.1787.

RUEHL, W.W.; HART, B.L. Canine cognitive dysfunction. In: DODMAN, N.H.; SHUSTER, L. (Eds.). Psychopharmacology of animal behavior disorders. Malden: Blacwell Science, 1998. p.283-304.

SAS Institute. SAS/STAT user's guide. Cary, NC, 2011. Version 9.3. 